\title{
READING STRATEGIES USED BY SUCCESSFUL READERS OF ENGLISH DEPARTMENT STUDENTS OF STATE INSTITUTE FOR ISLAMIC STUDIES PADANGSIDIMPUAN
}

\author{
Riandry Fadilah Nasution, Eka Sustri Harida, \& Sojuangon Rambe \\ IAIN Padangsidimpuan \\ riandryfadilahnst@gmail.com; esha_stainpasid@yahoo.com; \& \\ sojuangonr@gmail.com
}

\begin{abstract}
Abstrak
Artikel ini mengeksplorasi strategi-strategi membaca yang digunakan oleh mahasiswa sebagai pembaca yang sukses dan mencari tahu srategi membaca yang dominan digunakan oleh mahasiswa. Untuk mengumpulkan data, penelitian ini dilakukan dengan metode deskriptif kualitatif pada jenis studi kasus. Informan penelitian adalah 9 mahasiswa Program Studi Bahasa Inggris yang telah melewati dua mata kuliah Reading Comprehension. Untuk mengumpulkan data dalam penelitian ini, pada peneliti melakukan dua jenis test yakni tes pilihan berganda dan essay untuk mengetahui Reading Comprehension mahasiswa dan pedoman wawancara untuk mengetahui strategi membaca yang digunakan. Dalam Analisa data, para peneliti melakukan reduksi data, display data, dan kesimpulan / verifikasi data. Hasil penelitian menunjukkan bahwa cukup banyak strategi membaca yang digunakan oleh succesfull readers di IAIN Padangsidimpuan, yakni looking the kind of the text and reading the passage, reading first paragraph, focusing on first and last paragraph, focusing on the first paragraph and reading the passage, and others. Strategy yang paling sering digunakan adalah focusing on the first sentence, and focusing on the last paragraph. Dari hasil penelitian ini, para peneliti menyarankan agar para pembaca lebih menggunakan strategu yang bervariasi dalam membaca agar supaya semakin meningkatkan kemampuan membaca mahasiswa ataupun pembaca.
\end{abstract}

Kata Kunci: Pembaca yang Sukses, Strategi Membaca, dan Membaca Pemahaman.

\begin{abstract}
This article is to explore reading strategies used by successful readers of English department and to describe the steps they used the strategies, and to identify the dominant strategies that they used. It was done with qualitative approach in a case study. The informants of the research were nine students of English department who have passed the reading comprehension subjects. To collect the data, researcher used two kind of tests (multiple choice and essay) for reading comprehension and interview guided to get the reading strategies they used. To analyze the data, researcher did data reduction, data display, and conclusion/verification. The result of the research are there were many reading strategies used by informants toward the test given, such as looking the kind of
\end{abstract}


the text and reading the passage, reading first paragraph, focusing on first and last paragraph, focusing on the first paragraph and reading the passage, and others. The steps that successful readers of English Department students of State Institute for Islamic Studies Padangidimpuan did in using the strategies were various. Based on the findings, the most dominant reading strategy used by successful readers of English department Students of State Institute for Islamic Studies Padangsidimpuan were focusing on the first sentence, and focusing on the last paragraph. From the result, it is suggested to the readers to apply various reading strategies in order to them be able in reading.

Keywords: Successful Readers, Reading Strategies, and Reading Comprehension.

\section{INTRODUCTION}

Reading is very important for every man in the world. Reading is very easy activity that can be done wherever, whenever, and however we want. There are lots of benefits of reading. Several of benefits of reading are increasing someone's self confidence and improving readers' thinking process

First, reading is important to increase someone's self confidence. Reading is about how someone fills his brain through what she or he reads. Someone will be less confident if he or she does not have knowledge or information that she wants to say. Otherwise, someone will be confident if she or he has the knowledge and information. Such like in discussing class, the students who read many sources will be more confident to present their paper than the students who do not read many sources. Students who have read the information or knowledge from many sources will be more active to deliver their paper in front of their friends. All the information and knowledge are gotten through reading.

Second, reading is so beneficial to improve readers' thinking process. Reading books require readers to think and imagine about different details in the book such as characters and plot; this provides them to improve our thinking process. Repeating a habit of reading and persuading the brain to be more buoyant and absorb more information will give them a great beneficial. It also obliges readers to focus on what they are reading for long periods. Reading is not only related to the development of knowledge but also it is related to people thinking capability. This capability will be the basic development of emotional, moral, and verbal intelligence. Moreover, this development determines what kind of person people would be. Therefore, reading is important for students both to develop their knowledge and to develop the way they think related to the development of moral, emotion, as well as verbal intelligence. 
However, reading is common problems of students. Students often get some difficulties in reading process. The researcher interviewed the students of English department in State institute for Islamic Studies Padangsidimpuan. Some students had difficulties in reading process, such as lack of motivation for reading, get difficulties to answer the questions after they reading the text, and do not know the strategy to make them enable to answer the questions, and also lack of vocabulary.

Parallel with the interview that researcher did with the lecturer of reading comprehension, Mrs. Eka Sustri Harida said that there were many students could not answer the questions in examination completely. It was because students are lack of vocabulary, lack of reading habits, and they do not able to apply the reading strategies in reading process. ${ }^{1}$ It can be proved from their results in learning reading comprehension subject.

Interestingly, from 122 students of English Department of seventh semester who have passed Reading Comprehension I, Reading Comprehension II, and Reading Comprehension III, researcher still found several students got mark higher than 90. In Reading Comprehension I, there were 16 students got mark higher than 90 from 122 students. In Reading Comprehension II, there were 13 students got mark higher than 90 from 122 students. In Reading Comprehension III, there was only one student got mark higher than 90 from 122 students. For those three Reading Comprehension only one students could hold her mark higher than 90 from 122 students. For Reading Comprehension I and Reading comprehension II, there were only nine students could hold their mark higher than 90. Then, the nine students are interesting to do a research.

Students who are excellent in reading comprehension I and reading comprehension II called successful readers. Successful readers here are the students who got mark higher than 90 and could hold it in two reading comprehensions. It also can be proved from their achievement in reading comprehension subjects that they got the good results.

Moreover, strategies play an important role in reading a foreign language text. Many researchers have found that reading by using strategies are able to help students to read effectively and efficiently. They also had found that reading

${ }^{1}$ Eka Sustri Harida, Private Interview, Lecturer of Reading Comprehension, (IAIN Padangsidimpuan: November $\left.7^{\text {th }}, 2017\right)$. 
strategies had significant contribution for learning English, especially in reading classes for comprehending English text. Reading strategies can improve students' reading comprehension. Therefore, the students should have many and various strategies in reading to make them easier in understanding texts.

For those reasons, these cases are interesting to do a research, researcher wants to know what their reading strategies in reading comprehension are, why they used those reading strategies, and what reading strategies are dominant to use in reading comprehension. It can help the others students who got low mark in reading comprehension and got difficulties in reading process to solve their problem. They can imitate the reading strategies used by successful readers. Therefore, the researcher is interested in conducting this research.

This article tries to explore reading strategies and the steps used by successful readers of English Department students of State Institute for Islamic Studies Padangsidimpuan in reading comprehension, and the dominant reading strategies used by successful readers of English Department students of State Institute for Islamic Studies Padangsidimpuan in reading comprehension.

\section{REVIEW OF LITERATURE}

\section{Description of Reading Comprehension}

Reading comprehension is a complex process that include many components. The readers should be able to recall or to interpretate information after reading. Klinger describe that reading comprehension is a multicomponent, highly complex process that involves many interactions between readers and what they bring to the text (previous knowledge, strategy use) as well as variables related to the text itself (interest in text, understanding of text types). ${ }^{2}$ So reading comprehension is successful interaction between readers and the text in the complex process in order to get the intended meaning from the text.

Ministry of Education Ontario states reading comprehension - the process of making sense of text - is a complex, multifaceted activity that calls on the reader's thinking and problem-solving skills. ${ }^{3}$ M. Rahmani \& K. Sadeghi states

${ }^{2} \mathrm{~J}$. K. Klingner, et al., Teaching Reading Comprehension to Students with Learning Difficulties, ebook, (New York: The Guilford Press,2007) p.8.

${ }^{3}$ Ministry of Education, A Guide to Effective Instruction in Reading: Kindergarten to Grade 3, ebook, (Ontario: Queens' Printer, 2003), p.83. 
that reading comprehension is an interactive mental process between the reader's linguistic knowledge, knowledge of the world, and knowledge of the topic. ${ }^{4}$ In addition, Harida ${ }^{5}$ and Harida ${ }^{6}$ also stated that reading comprehension is the process of the readers to reconstruct the meaning from what the readers read. So, the readers have to reconstruct the author's message. If the readers can read the words of a text, but get nothing about what they are reading, they are not really reading.

From the explanations above, it can be concluded that reading comprehension is an active complex process in which the readers try to construct meanings through any information from a text, evaluate the information, and then compare the information in the text with their background knowledge.

\section{The Goals of Reading}

As the other skills, reading also has goals to develop reading comprehension. The goals mean there are some point that the readers can get from reading. Here are some goals of reading such as:

1) Reading for identifying important information/ for detail or facts.

2) Reading for main ideas.

3) Reading sequence or organization.

4) Reading for inference.

5) Reading to classify.

6) Reading to evaluate.

7) Reading to compare or contrast. ${ }^{7}$

The other aims or purposes of reading are:

1) To obtain information for some purpose or because we are curious about some topic

${ }^{4}$ M. Rahmani \& K. Sadeghi, 2011, Effects of Note Taking on Reading Comprehension And Recall, International Journal of Humanities and Social Science, 11(2), 116-128, Retrieved from http://www.ijhssnet.com accessed on November, 11th 2017.

${ }^{5}$ Eka Sustri Harida, "An Evaluation of the Students' Reading Motivation and Reading Comprehension of the Grade Three English Program IAIN Padangsidimpuan," Tazkir 3, no. 1 (2017): 183-94, https://doi.org/http://dx.doi.org/10.24952/tazkir.v3i1.729.

${ }^{6}$ Eka Sustri Harida, “USing Critical Reading Strategies: One Way for Assessing Students' Reading Comprehension," ISELT-4, 2016, 199-206, https://goo.gl/a3zyri.

${ }^{7}$ Henry Guntur Tarigan, Membaca Sebagai Suatu Keterampilan Berbahasa, (Bandung: Angkasa, 2005), p. 9. 
2) To obtain instruction on how to perform some task for our work or daily life (examples, knowing how an appliance works)

3) To act in a play, play a game, play a puzzle

4) To keep in touch with friends by correspondence or to understand business letters

5) To know when or where something will take place or what is available

6) To know what is happened (as reported in newspaper, magazine, reports, etc).

7) For enjoyment or excitement. ${ }^{8}$

Rizki Fiprinita says the purpose of reading is to connect the ideas on the page to what readers already know ${ }^{9}$. If the readers do not know anything about a subject, then pouring words of text in to readers' mind is like pouring water in to readers' hand. Readers do not retain much.

Usually the main purpose behind readers' reading is to make connections between what readers already know and what readers need to know. ${ }^{10}$ Knowing why readers are reading will greatly increase readers' chances of understanding the material. And there are many reasons why readers might be reading some particular text, they are pleasure and enjoyment, practical application, getting overview, and knowing specific information.

In conclusion, the purposes of reading comprehension can be various. It depends on situation and circumstances. Academically, reading is used for comprehending either written or spoken text. Even the purposes of reading might be just for filling the spare time or just increasing the knowledge.

\section{Levels of Reading Comprehension.}

There are four categories of reading comprehension. As stated by Burns et. al in Muhammad Situmorang's journal that reading comprehension is divided into four categories: Literal reading, interpretive reading, critical reading, and creative reading.

1) Literal comprehension

${ }^{8}$ David Nunan, Designing Tasks for the Communicative Classroom, (the United Kingdom: Cambridge University Press, 1989), p.33-34.

${ }^{9}$ Rizki Fiprinita, Reading 1,( Cadas Perss, 2003) P. 3-5.

${ }^{10}$ Rizki Fiprinita, Reading 1,( Cadas Perss, 2003) P. 3-5.. 
Reading for literal comprehension acquiring information that is stated directly in a selection. In literal reading, the main ideas are directly stated in the text. The reader needs only to understand exactly what is stated to receive the author's literal message. Literal comprehension is generally accepted as the most simple or basic comprehension skill and one that requires little thinking and reasoning. Recognizing sated main ideas details, causes, effect and sequences as the basis and understanding of vocabulary, sentences meaning, and paragraph meaning is important.

2) Interpretation Interpretive reading identifies the way to read between the lines of making inferences. This is the process of deriving ideas that implied rather than directly stated. Skill for this level of comprehension includes:

a) finding main ideas of passage in which main ideas are not directly sated

b) finding cause and effect relationship when they are not directly stated

c) Determining referents of pronouns

d) Determining referents of adverbs

e) Inferring omitted words

f) Detecting moods

g) Detecting author's purpose in writing

h) Drawing conclusion

3) Critical Reading Critical comprehension is evaluating written material, comparing the ideas discovered in the material with known standards and drawing conclusions about their accuracy, appropriateness and timeliness. When the reader read critically, they evaluate what is read. The critical reader must be an active reader, questioning, searching for facts and suspending judgment until he or she considered all of material. They examine critically the thoughts of the author, which have been identified through the lower level of comprehension and judge their validity or worth.

4) Creative Reading In creative reading, the reader must be able to think and to use their imaginations. Creative reading going beyond what the author has written, applying the ideas from the text to new situations and recombining the author's ideas with other ideas to form new concepts or 
to expand old ones. The reader must understand cause- effect relationship in a text although it is not stated directly. Through creative reading, the reader creates something new ideas, the solution to a problem, a new way of looking at something from the ideas gleaned from the text. ${ }^{11}$

Based on explanations above, it can be concluded that there are four levels of reading comprehension, they are literal comprehension, interpretation comprehension, critical reading, and also creative reading.

\section{Description of Reading Strategies}

Reading strategies are important to do by the readers in reading process. reading strategies help the readers to comprehend the text. Reading strategies are the plans for solving problems encountered in constructing meaning. ${ }^{12}$ The reader can help himself to solve his problems in reading through strategies. It can be concluded that reading strategies are the tactics of readers to solve his problem in reading.

Further, reading strategies can improve reading understanding. reading strategies help improve students' performances on test of comprehension. ${ }^{13}$ So reading strategies are useful to improve readers' comprehension. By using strategies in reading can make the readers easier to comprehend or understand the text. Reading strategies is the broad term used to describe the planned and explicit actions that help readers translate print to meaning. ${ }^{14}$ So reading strategies is an planned action to comprehend text better.

So, it can be concluded that reading strategies are ways, planned action, or procedures to get meaning or to reach goal in comprehending text, and also for solving the problems in constructing meaning.

\footnotetext{
${ }^{11}$ Muhammad Faisal Situmorang \& Bachtiar, Improving Students' Achievement In Reading Report Text By Using Think - Pair Share Strategy, accessed from http://jurnal.unimed.ac.id/2012/index.php/eltu/article/view/1378/1137, retrieved on November 11 ${ }^{\text {th }}, 2017$ at 04:06 pm.

${ }^{12}$ Richard Jack C, and Willy A. Renandya, Methodology in language Teaching, (Cambridge: Cambridge University Press, 2002), p. 287.

${ }^{13}$ Richard Jack C, and Willy A. Renandya, Methodology in....., p. 288.

${ }^{14}$ Reading Horizon, Reading Strategies Effective Reading Instruction Includes ResearchBased Reading Strategies, accessed from https://www.readinghorizons.com/reading-strategies/, retrieved on November $11^{\text {th }}, 2017$ at $10.15 \quad \mathrm{pm}$.
} 


\section{Kinds of Reading Strategies}

There are many reading strategies that can be used by the readers in activity of reading. The strategies will help them in comprehending the text. There are many kinds of reading strategies to help the readers in order to reach their purposes in reading.

Kathleen T. McWhorter says that effective reading is not a single step process, but a complex set of skills involving activities before, during, and after reading. Here is a partial list of some of those skills.

1. Before reading:

(a) Determining the subject of the material,

(b) Determining how the material is organized,

(c) Identifying what you need to remember from the material,

(d) Defining your purpose for reading.

2. During reading:

(a) Identifying what is important,

(b) Determining how key ideas are supported,

(c) Identifying patterns of thought,

(d) Drawing connections among ideas,

(e) Anticipating what is to come next,

(f) Relating ideas to what you already know.

3. During and after reading:

(a) Identifying the author's purpose for writing,

(b) Analyzing the writer's technique and language,

(c) Evaluating the writer's competence or authority,

(d) Asking critical questions,

(e) Evaluating the nature and types of supporting evidences..$^{15}$

Thus, an efective reading is through several steps. It means that the readers need to pay attention to the steps that will probably help them in getting what they need in reading.

In addition, Brown suggests that there are some strategies that can be used by the readers. The strategies are:

1. Identify the purpose of reading,

${ }^{15}$ Kathleen T. McWhorter, Efficient and Flexible Reading, (Niagara County Community College: Harper Collins Publisher, 1992), p. 23-24 
2. Use grapheme rules and patterns to aid in bottom-up decoding,

3. Use efficient silent reading techniques for relativity rapid comprehension,

4. Skimming,

5. Scanning,

6. Smantic mapping,

7. Guessing,

8. Vocabulary analysis,

9. Distinguish between literal and implied meanings, and

10. Capitalize on discourse markers to process relationship. ${ }^{16}$

Readers are supposed to identify the purpose of reading prior to the next steps mentioned. It means that the readers have to realize what their reading process for. Then, the readers may apply the next steps mentioned.

While the others reading strategies are Top-down, Bottom-up, and Interactive strategies. Here is the explanation of those strategies:

1. Top-down strategies

Top-down strategies begin with the reader's hypotheses and predictions about the text and his or her attempts to confirm them by working down the smallest unit of the printed text. ${ }^{17}$ In top-down strategies readers can use predictions, activating background knowledge, and then checking confirmation or refutations of the predictions. Top-down strategies begin from the general ideas to the specific one. The readers try to understand the text by interprating text through their experiences and background knowledge.

2. Bottom-up Strategies

Bottom-up strategies refer to the decoding of individual linguistics unit on the printed page, working one's way up from smaller to larger units to obtain the meaning and to modify one's prior knowledge. ${ }^{18}$ The readers try to understand the text with building textual meaning from the smallest units to the largest units.

3. Interactive Strategies

${ }^{16} \mathrm{H}$. Dauglas Brown, Strategies for Success: A Practical Guide to Learning English, (New York: Addison wesley Longman, inc. 2002), p. 306-310.

${ }^{17}$ David Nunan, Practical English Language Teaching, $1{ }^{\text {st }}$ edition (New York: McGraw Hill, 2003), p.70.

18J.Michael O'Malley \& Lorraine Paldez Pierce. Authentic Assessment for English Language Learners (USA: Addison-Wesley Publishing Company, Inc., 1996), p.94. 
Interactive models combine elements of both bottom-up and topdown models assuming "that a pattern is synthesized based on information provided simultaneously from several knowledge sources". ${ }^{19}$ The interactive process in reading will be occurred when the readers make an interactive process or work between the top-down strategies and bottom-up strategies.

Further, Effective readers use strategies to understand what they read before, during, and after reading.

1. Before reading, they:

a) Use prior knowledge to think about the topic.

b) Make predictions about the probable meaning of the text.

c) Preview the text by skimming and scanning to get a sense of the overall meaning.

2. During reading, they:

a) Monitor understanding by questioning, thinking about, and reflecting on the ideas and information in the text.

3. After reading, they:

a) Reflect upon the ideas and information in the text.

b) Relate what they have read to their own experiences and knowledge.

c) Clarify their understanding of the text.

d) Extend their understanding in critical and creative ways. ${ }^{20}$

To sum up, in order to get aim in reading, readers need some tactics or ways. The ways will help readers to comprehend the text easier and better. Again, readers need to pay attention to some steps that probably help readers in getting ideas from the text they read.

\section{Definition of Successful Readers}

Successful is getting something well or it can be said as doing something and getting a satisfied result. Successful means achieving or having achieved success. Readers are people who read. So the successful readers are the readers who have good achievement in reading process.

${ }^{19}$ David Nunan, Practical English........p. 72.

${ }^{20}$ Reading Strategies, THINK LITERACY: Cross-Curricular Approaches, Grades 7-12, accessed from www.edu.gov.on.caleng/studentsuccess/thinkliteracy/files/Reading.pdf, retrieved on April $8^{\text {th }}, 2018$ at $10.15 \mathrm{pm}$. 
Successful readers are those who are actives in reading process. Kathleen T. McWhorter says that active readers read each assignment differently, analyze the purpose of an assignment, adjust their speed to suit their purpose, question ideas, compare and connect textbook, reading with lecture content, find out what an assignment is about before reading it, keep track of their level of comprehension and concentration, read with pencil in hand, highlighting, jotting notes, and marking key vocabulary. ${ }^{21}$ Thus, someone can be called as a successful readers if he or she does those steps mentioned above figured by McWhorter.

From the explanation above, it can be concluded that the successful readers are the readers who are active in reading process. The successful readers get high achievement in reading by using precise strategies.

\section{RESEARCH METHODOLOGY}

This research was a qualitative approach and it is a case study. Informants in this research were students of English Department State Insitute for Islamic Studies Padangsidimpuan who have passed Reading Comprehension subjects and could hold their mark higher then 90 in Reading Comprehension I and Reading Comprehension II. Researcher did testing and interviewing in collecting data. In analizing the data, researcher used data reduction, data dispaly, and conclusion/verification.

\section{FINDINGS AND DISCUSSION}

\section{Findings}

\section{Reading Strategies and the Steps Used by Successful Readers of English Department Students of State Institute for Islamic Studies Padangsidimpuan}

There were many reading strategies used by successful readers of English Department students of State Institute for Islamic Studies Padangsidimpuan toward the reading comprehension test given. They were looking the kind of the text and reading the passage, reading first paragraph, reading one or two sentence in each paragraph, focusing on first and last paragraph, focusing on the first paragraph and reading the passage, reading passage quickly, focusing on tyhe first sentence, skimming, scanning, looking at the key words, regarding to the text and context, regarding to the

\footnotetext{
${ }^{21}$ Kathleen T. McWhorter, Efficient and Flexible ...., p. 24.
} 
words before vocabulary, guessing, and fousing on the last paragraph. The steps that they used were various.

\section{Dominant Reading Strategies Used by Successful Readers of English Department}

\section{Students of State Institute for Islamic Studies Padangsidimpuan}

The use of reading strategies by informants sorted from the most dominant to the least dominant are follows:.

a. Focusing on first sentencewas used by nine or all informants in identifying Topic Sentence

b. Focusing on last paragraph was used by nine or all informants in identifying conclusion.

c. Reading first paragraph was used by three informants in identifying topic.

d. Regarding to the text and context was used three informants in identifying vocabulary.

e. Regarding to the text before vocabularywas used by three informants in vocabulary.

f. Focusing on first and last paragraphwas used by two informants in identifying topic.

g. Looking the kind of text and reading the passage was used by one informant in identifying topic.

h. Reading one or two sentence in each paragraph was used by one informant in identifying topic.

i. Focusing first paragraph and read the passage was used by one informant in identifying topic.

j. Reading passage quickly was used by one informant in identifying topic.

k. Skimming was used by one informant in identifying important information.

1. Scanning was used by one informant in identifying important information

$\mathrm{m}$. Looking at the key words was used by one informant in identifying important information.

Based on the findings above, there were nine $(100 \%)$ of the informants used focusing on the first sentence in identifying topic sentence, and Focusing on the last paragrapah in identifying conclusion. It can be concluded that the most reading strategies used successful readers of Englsih Department students of 
State Institute for Islamic Studies Padangsidimpuan toward the test given were focusing on the first sentence, and focusing on the last paragraph.

\section{Dicussion}

By looking on the result of interviews, the researcher found that the successful readers of English Department students of State Institute for Islamic Studies Padangsidimpuan used many reading strategies to answer the test given. The reading strategies used by them were looking the kind of the text and reading the passage, reading first paragraph, focusing on first and last paragraph, focusing on the first paragraph and reading the passage, reading passage quickly, focusing on the first sentence, skimming, scanning, looking at the key words, regarding to the text and context, regarding to the words before vocabulary, guessing, and fousing on the last paragraph.

Skimming was one of the strategies that the informants used. This strategy was the dominant strategy used by informants toward the text given. Skimming was used by successful readers of English Department students of State Institute for Islamic Studies Padangsidimpuan in identifying topic, and important information. Brown suggests that skimming is one of reading strategies that can be used by readers. ${ }^{22}$ Further an effective readers preview the text by skimming and scanning to get a sense of overall meaning. ${ }^{23}$ Therefore skimming is suggested to be done in activity of reading.

Scanning was used by informants. Brown also suggests this strategy in reading. ${ }^{24}$ Informants used scanning when they found question about specific information. They used this strategy to identify important information. Scanning helped them to find the specific information easier.

Guessing was one of reading strategies used by the informants. They used it in identifying vocabulary. Brown suggests than one of reading strategies that can be used in reading activity is guessing. ${ }^{25}$ The informants guessed the meaning of vocabulary by considering of the text and context. Therefore, it helped them in identifying vocabulary.

${ }^{22}$ H. Dauglas Brown, Strategies for Succes ...... p. 306-310.

${ }^{23}$ Reading Strategies, THINK LITERACY: Cross-Curricular.... ${ }^{24} \mathrm{H}$. Dauglas Brown, Strategies for Success...... p. 306-310.

${ }^{24}$ H. Dauglas Brown, Strategies for Success...... p. 306-310.

${ }^{25} \mathrm{H}$. Dauglas Brown, Strategies for Success...... p. 306-310,. 
Thus, successful readers of English department used those strategies above in getting the indicators of reading comprehension on the test. They were identifying topic, identifying topic sentence, identifying important information, identifying vocabulary, and identifying conclusion. Therefore, those strategies helped them to be easier in answering the test given. As stated by many researches, such as $\mathrm{Hacer}^{26}$, Suri ${ }^{27}$, Guthrie ${ }^{28}$, and Ashadi ${ }^{29}$ that reading strategies have good effect to students' reading comprehension. Moreover, it has also been found that the successful readers used various kinds of reading strategies in their reading activities....Thus, it is known that reading strategies will make the students are better in comprehending what the readers read. So what has been found in this research is supported to what the researchers before, that reading strategies are helpful for students' reading comprehension, it is seen form the result that the successful readers used various reading strategies in their reading activities.

Moreover, the trustworthiness of these findings had been checked by triangulation. Researcher had checked the trustworthiness of these finding by confimed the result of interview one another. Researcher confirmed all the informants' result of interview. The result showed that the data have been in the truthfulness condition.

In the final analysis, it can be seen that there was no specific reading strategies used by successful readers of English Department State Institute for Islamic Studies Padangsidimpuan. So, it is assumed that they have been succeed in reading because they have high IQ not because of the strategies.

${ }^{26}$ Hacer Ulu and Hayati Akyol, “The Effects of Repetitive Reading and PQRS Strategy in the Development of Reading Skill," Eurasian Journal of Educational Research, no. 63 (2016): 225-42, https://doi.org/10.14689/ejer.2016.63.13.

${ }^{27}$ Ahmad Suri, "The Effect of Context Clues in Reading Comprehension of the Eleventh Grade Students at SMA Negeri 3 Palangkaraya" (2015), http://digilib.iain-palangkaraya.ac.id/204/.

${ }^{28}$ John T. Guthrie et al., "Increasing Reading Comprehension and Engagement through Concept-Oriented Reading Instruction," Journal of Educational Psychology 96, no. 3 (2004): 403-23, https://doi.org/10.1037/0022-0663.96.3.403.

${ }^{29}$ Ashadi Kurniawan, “Improving Students' Reading Comprehension on Narrative Text Through Story Mapping Strategy English Education Study Program Language and Arts Education Department Teacher Training and Education Faculty Pontianak Improving Students ' Reading Comprehension," 2013,1-13. 
278 | TAZKIR: Jurnal Penelitian Ilmu-ilmu Sosial dan Keislaman

Vol. 04 No. 2 Desember 2018

\section{CONCLUSION AND SUGGESTION}

\section{Conclusion}

From the result of this research it can be concluded that the successful readers of English Department students of State Institute for Islamic Studies Padangsidimpuan used various reading strategies in their reading activities, such as looking the kind of the text and reading the passage, reading first paragraph, focusing on first and last paragraph, and so on. The most dominant reading strategies that they used toward the test givenwere focusing on the first sentence, and focusing on the last paragraph. There were nine (100\%) of the informants used focusing on the first sentence in identifying topic sentence, and focusing on the last paragrapah in identifying conclusion.

\section{Suggestions}

Based on the conclusions above, researcher suggested as the students to find their own strategies that appropriate for themselves. Everyone can succeed with different strategies and use the strategies in their reading activities. As known that reading strategies can make the other students become successful readers. 


\section{REFERENCES}

Ahmad Suri. "The Effect of Context Clues in Reading Comprehension of the Eleventh Grade Students at SMA Negeri 3 Palangkaraya," 2015. http://digilib.iain-palangkaraya.ac.id/204/.

Brown, H. Dauglas, Strategies for Success: A Practical Guide to Learning English, New York: Addison Wesley Longman, inc. 2002.

Guthrie, John T., Allan Wigfield, Pedro Barbosa, Kathleen C. Perencevich, Ana Taboada, Marcia H. Davis, Nicole T. Scafiddi, and Stephen Tonks. "Increasing Reading Comprehension and Engagement through ConceptOriented Reading Instruction." Journal of Educational Psychology 96, no. 3 (2004): 403-23. https://doi.org/10.1037/0022-0663.96.3.403.

Harida, Eka Sustri. "An Evaluation of the Students' Reading Motivation and Reading Comprehension of the Grade Three English Program IAIN Padangsidimpuan." Tazkir 3, no. 1 (2017): 183-94. https://doi.org/http://dx.doi.org/10.24952/tazkir.v3i1.729.

- - . “USing Critical Reading Strategies: One Way for Assessing Students' Reading Comprehension." ISELT-4, 2016, 199-206. https://goo.gl/a3zyri.

_ _ $\_$Reading strategies Used by English Department Students of Muhammadiyah University, Unpublished Thesis, Graduate Program of State University of Padang, 2007.

Harmer, Jeremy, The Practice of English Language Teaching Third Edition Completely Revises and Update, e-book, England: Longman, 2003.

The Practice of English Language Teaching, e-book, Edinburgh: Pearson Education Limited, 2001.

Jack C, Richard and Willy A. Renandya, Methodology in language Teaching, Cambridge: Cambridge University Press, 2002.

Kurniawan, Ashadi “Improving Students ' Reading Comprehension on Narrative Text Through Story Mapping Strategy English Education Study Program Language and Arts Education Department Teacher Training and Education Faculty Pontianak Improving Students ' Reading Comprehension," 2013, 113.

Klingner, J. K, et al., Teaching Reading Comprehension to Students with Learning Difficulties, e-book, New York: The Guilford Press, 2007. 
280 | TAZKIR: Jurnal Penelitian Ilmu-ilmu Sosial dan Keislaman

Vol. 04 No. 2 Desember 2018

M. Rahmani \& K. Sadeghi, 2011, Effects of Note Taking on Reading Comprehension And Recall, International Journal of Humanities and Social Science, 112, 116-128, retrieved from http://www.ijhssnet.com accessed on November, 11th 2017 at 10. 20 Pm.

McWhorter, Kathleen T., Efficient and Flexible Reading, Niagara County Community College: Harper Collins Publisher, 1992.

Ministry of Education, A Guide to Effective Instruction in Reading: Kindergarten To Grade 3, e-book, Ontario: Queens' Printer, 2003.

Nunan, David, Practical English Language Teaching, New York: Mc. Grow-Hill Company, 2003.

_ _ _ Designing Tasks for the Communicative Classroom the United Kingdom: Cambridge University Press, 1989.

O 'Malley, J. Michael \& Lorraine Paldez Pierce, Authentic Assessment for English Language Learners, USA: Addison-Wesley Publishing Company, Inc., 1996.

Reading Horizon, Reading Strategies Effective Reading Instruction Includes Research-Based Reading Strategies, accessed from https://www.readinghorizons.com/reading-strategies/, retrieved on November $11^{\text {th }}, 2017$ at $10.15 \quad \mathrm{pm}$.

Reading Strategies, THINK LITERACY: Cross-Curricular Approaches, Grades 712, accessedfrom www.edu.gov.on.caleng/studentsuccess/

thinkliteracy/files/Reading.pdf,retrieved on April 8th 2018 at $10.15 \mathrm{pm}$.

Rizki Fiprinita,Reading 1, Cadas Perss, 2003.

Situmorang, Muhammad Faisal \& Bachtiar, Improving Students' Achievement In Reading Report Text By Using Think-Pair Share Strategy, accessed from http://jurnal.unimed.ac.id/2012/index.php/eltu/article/view/1378/113,retrie ved on November 11 $11^{\text {th }}, 2017$ at 04:06 $\mathrm{pm}$.

Tarigan, Henry Guntur, Membaca Sebagai Suatu Keterampilan Berbahasa, Bandung: Angkasa, 2005.

Ulu, Hacer, and Hayati Akyol. "The Effects of Repetitive Reading and PQRS Strategy in the Development of Reading Skill." Eurasian Journal of Educational Research, no. 63 (2016): 225-42. https://doi.org/10.14689/ejer.2016.63.13. 